\title{
Yoga as Synthesis. Yoga as Revival. Eugeniusz Polończyk's Vision of Yoga. Contribution to the Study of the History of Yoga in Interwar Poland
}

\author{
Agata Świerzowska \\ Chair for Comparative Studies of Civilizations \\ Jagiellonian University
}

\begin{abstract}
The study of the history of yoga in Poland has only just begun, and knowledge about the earliest stages of the reception of the idea in thi country is so far negligible. This paper is an attempt to broaden the current state of knowledge on yoga in Poland in the interwar period. It focuses on the interpretation/understanding of yoga presented by Eugeniusz Polończyk (?-1932), a medical doctor, social activist and esotericist. Polończyk's interpretation of yoga forms an integral part of his socio-political views. It may be seen as an attempt to strengthen his synarchist beliefs as well as a way to introduce them into the practice of social life in order to enable the revival of the Polish nation and create an ideal (utopian) state. The paper also highlights the most characteristic features of interpretations of yoga in Poland in the interwar period - patriotic, messianic, Christian and esoteric.
\end{abstract}

Key words: Eugeniusz Polończyk, Wincenty Lutosławski, Józef Świtkowski, Alexandre SaintYves d'Alveydre, raja yoga, Theosophy, esotericism, synarchy

Słowa kluczowe: Eugeniusz Polończyk, Wincenty Lutosławski, Józef Świtkowski, Alexandre Saint-Yves d'Alveydre, radźa joga, teozofia, ezoteryzm, synarchia

Yoga arrived in Poland in the first decade of the $20^{\text {th }}$ century. The year 1905 , when the first Polish yoga textbook was composed, may be considered as the beginning of the process of adapting yoga to the cultural reality of this part of the world. The term "Polish" used here refers to the fact that the book was written in Polish by a Pole who himself practised yoga, and even considered himself to be a yogi. This is the idea expressed by Elizabeth de Michelis, who linked the beginnings of Modern Yoga with " $[\ldots]$ what seems to be the first recorded affirmation, by a Westerner, that 
he considered himself a yoga practitioner - after a fashion." ${ }^{1}$ Here Michelis is recalling American transcendentalist Henry David Thoreau, who, in one of his letters, called himself a yogi. Michelis stresses:

Up to that point the West had known about (and had been interested in) yoga and yogins, but these were seen as altogether "other". Yoga, that is, was in no way perceived as an option to be taken up by Westerners; it was a phenomenon observed, studied and reported about in third person, as it were. There had, of course, been a few cases of Westerners "going native" and becoming absorbed in Oriental (including monastic) cultures - but that was another matter. In Thoreau's case yoga was taken up by a Westerner while remaining a Westerner. ${ }^{2}$

In Poland, it seems, the first person who saw yoga as a strategy which may be successfully adopted by Westerners without losing their identity was Wincenty Lutosławski (1863-1954), a philosopher, writer, social activist and reformer who not only practised various yoga techniques but clearly considered himself to be a yogi and even claimed to possess supernatural powers - siddhis. ${ }^{3}$ Since Lutosławski considered yoga to be especially suitable for the Polish nation, he produced a book, today commonly referred to as the first Polish yoga textbook, Rozwój poteggi woli przez psychofizyczne ćwiczenia wedlug dawnych aryjskich tradycji oraz wtasnych swoich doświadczeń podaje do użytku rodaków Wincenty Lutostawski [The Development of the Power of Will through Psychophysical Exercises according to the Ancient Aryan Traditions and His Own Experiences Given by Wincenty Lutosławski for the Use of His Compatriots]. The textbook - and this is particularly important - presented a version of yoga adapted to the specific needs of the Polish nation that, due to historical circumstances, ${ }^{4}$ was faced with an urgent necessity for revival - physical, moral and spiritual. In Lutosławski's vision, Polish yoga was to be understood as a form of self-help and a strategy for national rescue - a certain lifestyle as well as a system of practices ${ }^{5}$ which may or even should be adopted by the Poles in order to bring about the renewal of the nation. This in turn was to bring Poland freedom in every sense. Lutosławski wrote:

${ }^{1}$ E. De Michelis, A History of Modern Yoga. Patanjali and Western Esotericism, London-New York 2005 , p. 2.

${ }^{2}$ Ibidem, p. 3.

3 The best evidence of Lutosławski's attitude to yoga and his own yoga practice are his letters to American philosopher and psychologist William James (1842-1910), with whom Lutosławski corresponded for almost 17 years. Cf. A. Świerzowska, Listy o jodze. Wincenty Lutostawski do Williama Jamesa [in:] Joga w kontekstach kulturowych 2 - 05 Listy o jodze. Wincenty Lutostawski do Williama Jamesa, Katowice 2017, pp. 67-92.

${ }^{4}$ Poland lost its independence as the result of the three partitions in 1772, 1793 and 1895 . The territory of Poland was divided between the Russian Empire, the Kingdom of Prussia and the Habsburg Monarchy of Austria. Poland regained its sovereignty in 1918.

${ }^{5}$ Lutosławski's main sources of inspirations for his yoga textbook were: for the practical side of the system Yogi Ramacharaka (William Walter Atkinson, 1862-1932) and Genevieve Stebbins (1857-1934); for the theoretical part Swami Vivekananda (1863-1902). For more information cf. A. Świerzowska, Esoteric Influences in Wincenty Lutostawski's Programme of National Improvement. Prolegomena, "The Polish Journal of the Arts and Culture (Esoteric Studies. Polish Contributions)" 2015, no. 1, pp. 147-173. 
There are no other possible exercises which could be practised so constantly, as the easiest and the simplest exercises of will. They will give peace, give strength and inspiration that will show the way out of the worst snare [...]. This is the way leading not only to physical and moral regeneration, but also to the independence most widely understood and permeating all the areas. $^{6}$

At this stage, yoga in Poland was not only patriotically oriented, but also had a very strong messianic bent which was of Romantic provenance. ${ }^{7}$ In this patriotic and messianic vision of yoga, Poland was supposed not only to find its own renewal (through yoga), but its ultimate goal was to lead the whole of humanity to and through a spiritual revolution. In other words, Poland was to be the messiah of nations, yet not to die for them, but to bring them moral and spiritual revival.

After Poland regained its independence in 1918, yoga retained its patriotic and messianic character, but it also adopted one more feature - it became entangled in esoteric ideas. This seems to be a natural consequence of the fact that during the interwar period Poland developed a very dynamic esoteric milieu well connected to and strongly influenced by its Western counterpart. One should not, of course, think that esoteric ideas were not present in Poland in earlier times. Just as was the case in the other parts of Europe, along with the modernism in Poland arrived its "sister" esotericism in the form of increased interest in mystical, magical and esoteric themes usually linked with the traditions of the ancient Near and Far East. However, due to the political situation, the dynamic development of all sorts of esoteric organisations, as well as a clear migration of the ideas on Polish territory, can be observed after 1918 (particularly strong centres of esotericism in Poland at that time were Lviv, ${ }^{8}$ Warsaw and Silesia). Among the organisations operating in Poland were Polskie Towarzystwo Teozoficzne [Polish Theosophical Society], Polskie Towarzystwo Astrologiczne [Polish Astrological Society], Towarzystwo Parapsychiczne im. Juliana Ochorowicza [Julian Ochorowicz Parapsychic Society], Polskie Towarzystwo Antropozoficzne [Polish Anthroposophical Society], Towarzystwo Studiów Ezoterycznych [Society for Esoteric Studies], Towarzystwo Metapsychiczne [Metapsychic Society], and Zakon Martynistów [The Order of Martinists], all of them with members and followers around the whole country, but there were also many much smaller, locally based organisations, such as Towarzystwo Alchemiczne [Alchemical Society], Koło Spirytystów [The Circle of Spiritists], Koło Mistyków [The Circle of Mystics], Towarzystwo Psychofizyczne [The Psychophysical Society] and various others. In total, at the turn of the century there were over 30 organisations focused on the dissemination of esoteric knowledge in Poland. ${ }^{9}$ The narratives coming out of these environments

${ }^{6}$ W. Lutosławski, Rozwój potęgi woli przez psychofizyczne ćwiczenia, Kraków 1909, pp. 179-180.

${ }^{7}$ I mean here Polish Romanticism, an intellectual and artistic period which began around 1820 and exposed, cherished and popularised messianic visions in which Poland was supposed to be the Messiah of the nations. The most prominent proponents of this idea were the so-called "Polish bards," Adam Mickiewicz (1798-1855) and Juliusz Słowacki (1809-1849). Mickiewicz also appears in Polończyk’s interpretation of yoga. I mention it briefly further in this paper.

${ }^{8}$ Up to 1945 (the Yalta Conference), Lviv remained within the borders of Poland.

9 B. Włodarz, Przestańcie tworzyć sekty! Czyli prośba o duchowe pojednanie, Warszawa 1933, pp. 9-10. 
- beyond the obvious esoteric message - often also exhibited patriotic postulates they translated esoteric concepts into political and social programmes aiming at rebirth, renewal and strengthening the Polish nation. Bractwo Odrodzenia Narodowego [Brotherhood of the National Revival] and Związek "Arja" [Arya Society], which will be mentioned below, may be named as the best examples of organisations focusing on this kind of activity. The groups named here as well as others, and the thinkers who drew inspiration from the "ancient wisdom of the East" (which usually meant theosophy) and other esoteric sources and mixed it with the Polish Romantic philosophy, highlighting the messianic themes, in different variants proclaimed organicism and elitism, criticised democracy, built totalitarian utopias, betrayed authoritarian tendencies or, less often, liberalism, sometimes even anarchic optics. Almost all of them were anti-nationalist (in the sense of imperialism and national chauvinism), locating the ultimate goal of their activity in humanity as such (with the exception of the Jews, as the majority of these activists voiced anti-Semitic slogans) and entrusted its realisation to the messiah of nations, i.e. Poland, and, in that sense, were heavily oriented towards national thinking. These narratives were never influential. None of them came into being in political reality. The actions undertaken, if any - as some of these visions remained on paper only - were of a niche character, although they demonstrate the ferment of ideas characteristic of Poland during the interwar period. Because of the obvious presence of authoritarian and elitist motifs in Polish esoteric thought at that time, and in particular its patriotic dimension, following Tomasiewicz, one may pose a question about the existence of the "esoteric sources of the Polish fascism," a question similar to the one posed by Nicholas Goodrick-Clarke in his book The Occult Roots of Nazism. ${ }^{10}$ According to Tomasiewicz, however, the answer to this question is negative - "The totalist groups of the next decade did not follow the path pointed out by the esotericists, more often seeking justification for their political system in Catholicism."

Among the many ideas that made up the Polish patriotic and esoteric conglomerate was also yoga, which came to Poland in a theosophical interpretation (which is hardly a surprise, since the Theosophical Society was one of the main channels for the internationalisation of yoga). And, it seems, because of this easily entered into esoteric discourse, becoming a strategy willingly indicated by the esotericists for the renewal - especially moral and spiritual - of the Polish nation, devastated by years of slavery. The theosophical vision of yoga, but supplemented with patriotic and Christian themes, dominated in Poland up until the outbreak of World War II. ${ }^{12}$

${ }^{10}$ N. Goodrick-Clarke, The Occult Roots of Nazism, London 2004.

11 J. Tomasiewicz, Naprawa czy zniszczenie demokracji? Tendencje autorytarne i profaszystowskie w polskiej myśli politycznej 1921-1935, Kraków 2012, p. 377.

12 Theosophy, though most strongly represented, was not the only one. During the interwar period, yoga in Poland was also influenced by Rudolf Steiner's anthroposophy. The second most popular textbook of yoga, after Lutosławski's The Development of the Power of Will, was Wstep w s'wiaty nadzmystowe. Radża joga nowoczesna [How to Enter the Higher Worlds. The Modern Raja Yoga] (1923), authored by the leading Polish parapsychologist and occultist Józef Świtkowski (1876-1942). Świtkowski's vision of raja yoga is almost entirely based on anthroposophy. 
In Poland, during the interwar years several patriotic, messianic and esoteric interpretations of yoga appeared. One of them was created by Eugeniusz Polończyk (?1932). His vision had a niche appeal, and never gained much popularity. Polończyk, it seems, never made any organisational efforts to put it into the wider, social practice of everyday life. The publications he authored, presenting the social and political programme that he had created, especially the executive programme for the Arya Society, do not suggest that he was engaged in any activity aimed at promoting this vision of yoga and applying it into practice. One may assume that Polończyk only envisioned and pointed to certain possibilities, without caring too much about their implementations. Despite the small range of Polończyk's influence and his ideas - and here I refer only to his interpretation of yoga - today it is certainly worth remembering for two reasons. Firstly, during the interwar period it was the only interpretation which formed part of the very complex socio-political programme of national and global revival also designed by Polończyk and described in his various publications, ${ }^{13}$ and secondly, it represents all the most characteristic features of Polish visions of yoga prevailing at this time, features which later (after World War II) would be lost almost entirely.

Information about Polończyk is very scant. He was a medical doctor practising in Lviv. He enjoyed considerable fame, probably due to the fact that he undertook the treatment of patients abandoned by official medicine. ${ }^{14}$ Since he did not trust, and in many respects totally rejected academic medicine, he practised so-called occult medicine as well as various forms of natural therapy. He made diagnoses and evaluated the condition of his patients with the help of a medium whom he himself entranced. The curative procedures he prescribed included magnetic treatments, a proper diet, fasting, rest, and hydropathy. The basic rule governing Polończyk's medical practice may be summarised as "going back to nature." This was nature which, according to the doctor from Lviv, was the best doctor, far more effective than the dehumanised and mechanised medical procedures applied in a hospital, i.e. a "factory and industrial plant with lots of different rooms full of machines and apparatus." ${ }^{15}$ It seems that Polończyk's approach may be considered as a good example of the Nature Cure trend which became popular in Europe from the late $19^{\text {th }}$ century, and which should be treated - as Alter highlights - "at least in part as a response to the increasingly specialized, invasive, and iatrogenically dangerous forms of allopathic practice that were current at the time." ${ }^{16}$ In this context, Polończyk's interest in yoga - in addition, as will be shown below, defined as "synthesis" - seems natural. We should add, however, that there are no hints that he recommended that his patients use any of the yoga procedures, such as those described by Yogi Ramacharaka in his numerous books. We may assume that Polończyk was familiar with them, and it would be

${ }^{13}$ Cf. mainly: E. Polończyk, Przyszły układ narodów, Lwów 1919; idem, Synteza przyszłości, "Hejnał" 1929, no. 2, pp. 42-48; idem, Przyszły ustrój ludzkości wedle źródel teozoficznych, Oedesa 1918; idem, Przyszłość Polski. Żydzi. Jehowa, Lwów 1921.

${ }^{14}$ A.K. Gleic, Glossariusz okultyzmu, Kraków 1936, p. 68.

${ }_{15}$ E. Polończyk, Lekarze i leczenie, Lwów 1918, p. 3.

16 J. Alter, Yoga in Modern India. The Body between Science and Philosophy, Princeton-Oxford 2004, p. 108. 
natural to search for an exchange of ideas, especially taking into account the popularity of Ramacharaka's vision of yoga in Europe ${ }^{17}$ and the fact that his two most famous books on yoga, Hatha Yoga, or the Yogi Philosophy of Physical Wellbeing (1904) and Science of Breath; a Complete Manual of the Oriental Breathing Philosophy of Physical, Mental, Psychic and Spiritual Development (1905), were already known in Polish translations. Both of them enjoyed considerable recognition in the soteric milieu in which Polończyk operated..$^{18}$ Based on the materials at our disposal, however, we cannot prove the undoubted existence of these influences.

Polończyk was also an active esotericist and socio-political visionary. These two realms closely intertwined in his views and actions. Polończyk willingly and with a flourish sketched his visions of a new world order, creating, as he called, it "a synthesis of revival"19 drawing abundantly from:

[...] the oldest monuments of knowledge known to mankind (the Book of Dzyan, Kapila's Sankhya composed around million years ago, the book of Manu and the Vedas from tens of thousands of years ago, the wisdom of Hermes, Laotsy, Buddha, Christ), [the theme of synthesis] concerns the knowledge of schools of philosophy as we know them, includes the secrets of all religious beliefs, penetrates national visions and even every detail of life. Taking millions of rays of true and false, living and dead, painful and delightful, the spirit of the seeker has to produce one harmonious, congruous and amiable shining centre of life... ${ }^{20}$

He announced his pro-reformatory ideas and visions in two esoteric journals - "Hejnał" [The Bugle Call] ${ }^{21}$ and "Wiedza filozoficzna" [The Philosophical Knowledge], ${ }^{22}$ as well as in the brochures published either at his own expense or by the Arya Society which he founded.

Polończyk was not content with mere theorising. He also tried to bring his ideas into the practice of social life. The result of his actions was the previously mentioned Arya Society, inaugurated in 1926 in Lviv. "Arya" probably emerged from the Brotherhood of the National Revival, which was founded in 1921 by the spiritist and exponent of palmistry Karol Chobot (1886-1937). Its aim was to establish the Kingdom of God on earth by creating a universal church of all the peoples, nations

${ }^{17}$ Cf. M. Singleton, Yoga Body. The Origins of Modern Posture Practice, Oxford 2010, p. $130 \mathrm{ff}$.

${ }^{18}$ Cf. A. Świerzowska, From Ramacharaka's "Standard of the Normal Man" to Lutostawski's Strategy of National Revival. How Ramacharaka's Interpretation of Yoga Fits with the Early Stage of Yoga Adaptation in Poland (forthcoming).

19 E. Polończyk, Arja. Część I (Synteza odrodzenia), Lwów 1924, p. I.

${ }^{20}$ Ibidem.

21 "Hejnał. Nad morzem życia ze szczytów prawd Ducha i praw Człowieka. Miesięcznik poświęcony wiedzy duchowej" [The Bugle Call. Over the Sea of Life from the Tops of the Spirit of Truth and Human Rights. Monthly Dedicated to Spiritual Knowledge] was published in 1929-1939 by the esotericist Jan Hadyna (1899-1971). The journal dealt with the subjects of spiritism, astrology, parapsychology, philosophy of the East, theosophy etc. "Hejnał" frequently promoted an esoteric and messianic version of Polish patriotism.

22 "Wiedza filozoficzna. Miesięcznik poświęcony materjałom Wiedzy syntetycznej i uprawie filozoficznej SŁOWA polskiego" [Philosophical Knowledge. Monthly Dedicated to the themes of Knowledge of Synthesis and the Philosophical Cultivation of the Polish WORD] was published by Zygmunt Tarło-Maziński (1889-1967), Freemason, Rosicrucian and the founder (in 1924) of the Polish Synarchic Society. The journal dealt with the issues of national philosophy and education, religion, and social politics. 
and religions. New, perfect man, directed in his actions by the "Spirit," was supposed to be the creator of this new order. The vision of the state proposed by Chobot was, in fact, a totalitarian utopia - the "soul" of the state envisioned as an organism was to be a government ruling over three social states (sages, clerks and the labour force); each of the classes was to be formed by institutions such as schools, press, theatres, museums etc. All social institutions were to serve the government so that it could carry out the planned activities. ${ }^{23}$ In this project Poland had a special role to play. The Polish nation, an Aryan one, was a seed of the highest "sixth race" with a unique spiritual character. As such, Poland could take the mission of the "Messiah of the Nations" and carry humanity through the spiritual revolution to start a new order on earth. The members of the Brotherhood of the National Revival did not put much effort into realising this vision. They did not try to convey it into the language of politics. The sole activity was the creation of the plans for the establishment of a self-sufficient settlement, which had never been fulfilled. ${ }^{24}$

Polończyk's vision, though quite different in general terms, shares many common points with the previous one. Tomasiewicz characterises it as conservative libertarian. ${ }^{25}$ In Polończyk's view, the "commonwealth with the king" would be the ideal political system, although the king would only perform representative and symbolic functions; a bicameral parliament was to be the actual ruling body. The bureaucratic apparatus was to be replaced by the civil service, the judicial system by the court of conciliation, and the regular army by the levée en masse. The society would be subdued into three classes, and its affiliation would be derived from one's innate abilities and talents. In the economic sphere, Polończyk called for freedom of labour, the introduction of voluntary taxes, and deurbanisation. According to Polończyk, to make this vision possible, it was necessary to "awaken life" 26 - and this was "Arya's" main goal. To "awaken life" meant, as Polończyk saw it, a systematic effort aimed at uniting, at creating a "synthesis" (in Polończyk's words) at all levels of social life. "Cooperation is life - division is death," explained Polończyk, while calling for "the restoration of the communication and coexistence between fighting groups and classes" ${ }^{27}$ - cities and countryside, workers and factory owners, between races, nations, faiths, between science and religion.

Polończyk's visions and projects, including the Arya Society, corresponded well with the ideas and actions of Western esotericists of that time, seeking ways and means which would gradually lead to the total transformation of humanity. Polończyk's propositions were, mutatis mutandis of course, parallel to the visions and the organisations sprouting out of them. These included the Theosophical Society in Adyar, the anthroposophic Gotheanum in Dornah, "Urusvati" - the Institute of Himalayan Studies

${ }^{23}$ Cf. The vision of such an ideal state was depicted in Zasady rzadu narodu Tolteków (Szkic z dziedziny okultyzmu), "Odrodzenie" 1921, no. 3, pp. 14-16 and Zasady rządu Tołteków (Ciag dalszy) , "Odrodzenie" 1921 , no. 4 , pp. 12-14.

${ }^{24}$ For more about this organisation cf. J. Tomasiewicz, op. cit., p. $353 \mathrm{ff}$.

${ }^{25}$ Ibidem, p. 360.

${ }^{26}$ E. Polończyk, Program wykonawczy Związu “Arja”. Rzeczpospolita z Królem, Lwów 1926, p. 15.

${ }^{27}$ Ibidem. 
initiated by Elena and Nikolai Roerich, George Ivanovich Gurdjieff's Château Le Prieuré "institute" at Fontainebleau-Avon, and Auroville, the City of Dawn founded near Pondicherry, which came about much later, but whose vision is rooted in the same bed of utopian thinking about the perfection of mankind. All of these groups, just like Polończyk's Arya Society, saw themselves as a kind of embryo of a new reality. The reconstruction and the revival of humanity, of the whole world, was supposed to begin with them and thanks to their actions - they were to be a place for the formation of the new generations according to various adopted principles. Despite all the differences, all of them placed a particular emphasis on the practice, on conscious moral improvement accompanying spiritual awakening and leading to a new, perfect reality. This kind of thinking was especially evident in the groups and thinkers who, like Polończyk, drew inspiration from the teachings of the Theosophical Society.

There are quite a few themes of oriental origin in Polończyk's works. Influenced by theosophy, he was convinced, just as many other esotericists of that time, that oriental wisdom, oriental thought, and particularly Indian tradition had a special value - that it represented the original, primordial wisdom, and hence was superior to European thought, dominated and degenerated by materialistic influences. In the tradition of the Orient, Polończyk sought the "tools" which might help him to put his reformatory ideas into practice. Yoga was one of them.

The interpretation of yoga proposed by Polończyk is a fusion of theosophical, Polish-patriotic and messianic themes. It is also possible to trace the clear influence of synarchic ideas quite common and popular in the esoteric environment in which Polończyk operated ${ }^{28}$ The Polish esotericist defines yoga, or to be precise, raja yoga - the "royal wisdom of the East" ${ }^{29}$ - as a "Hindu synthesis." ${ }^{30}$ In his vision, yoga is primarily an ability to look at reality in the right way and to act congruously according to a previously adopted correct world view. This kind of action would be consistent with the eternal laws of nature, which are always leading towards unity, towards synthesis. ${ }^{31}$

A yogi is able to combine appropriate and equivalent parts, organs and departments of the body with the same parts of humanity; he even goes further, linking in the same manner atoms and the universe. He estimates, reflects upon and recognises both in his body as well as in humanity the laws of health and disease, development and decline, rules and decay, he establishes the threads which allow him to see and feels in every thought one or more universes for which he alone is the balancing and connecting power. ${ }^{32}$

${ }^{28}$ The synarchic themes are very much visible in almost all of Polończyk's works. He cooperated with the previously mentioned Tarło-Maziński’s "Wiedza filozoficzna" [Philosophical Knowledge], but the possible relations between Polończyk's Arya Society and Tarło-Maziński's Polish Synarchic Society needs further research. Synarchic topics also frequently appeared on the pages of "Hejnal". The journal willingly propagated visions of the creator of the idea of synarchy, the French occultist Alexandre SaintYves d'Alveydre (1842-1909), whom I mention briefly in further parts of this paper.

${ }^{29}$ E. Polończyk, Czem jest Yoga?, Lwów 1921, p. 2.

${ }^{30}$ Ibidem, p. 8.

${ }^{31}$ This is how Polończyk characterises this "synthesising" nature of yoga: "Yoga, therefore, literally meaning 'binding,' and in the scientific language synthesis is establishing threads of strength, knowledge, feelings, life and immortality by combining the values which fade away quickly with the eternal ones. (Such hair must grow first, before the powerlessness transforms into strength)" (ibidem, p. 10).

${ }^{32}$ Ibidem, p. 8. 
It should be emphasised that Polończyk, like almost all esotericists of that time, especially those with a theosophical background, clearly opposed and contrasted raja and hatha yoga - the former being a purely spiritual and intellectual path, and the latter materialistic and egoistic, degenerated and with no deeper meaning. The true yoga, raja yoga, was not, as Polończyk stressed, a set of exercises, specific bodily discipline or practice; it did not cover breathing exercises, nor was it "escaping from life, flying on the sky of dreams, intoxicating with the play of imagination and mortifying the body in the paradise of nature and eternal spring on the slopes of the Himalayas." ${ }^{33}$ The practitioner of this original yoga should also not be confused with the image of a yogi that is common in the West, who "using various secret procedures, forces the body to produce some supernatural abilities and strengths." ${ }^{34}$ Polończyk also looked critically at the new interpretations of yoga, especially those emerging in India. He, again as was common in the esoteric circles of the time, emphasised the antiquity of raja yoga and linked its origins directly to "Upanishads, the greatest monument of human wisdom written down thirty thousand years ago," Mahabharata and Sankhya (though he did not refer here to any particular script). ${ }^{35} \mathrm{He}$ was convinced that "yoga exercises which are not based on the source of true knowledge lead the organisms of the practitioners to disease and degeneration." ${ }^{36}$ Unfortunately, as Polończyk noted, presently even India had lost almost entirely the ability to understand the original knowledge of yoga: "Today, none in Europe possesses the true knowledge of yoga. In India there are only few representatives of the true tradition, but they do not find respect either among Indians or in Europe." ${ }^{37}$ As a result, in India the true teachings of yoga had disappeared almost completely, and were replaced with "dozens of trends which under the banner of yoga teachings deform, distort and destroy the organisms of their students." 38

Polończyk claimed to return to the original and correct reading of the tradition of yoga, bringing back its real meaning, and hence using the opportunities it gives in a proper way, which is the transformation (renewal) of humanity. As previously mentioned, he saw raja yoga not as a certain practice, but rather as a framework (in compliance with the eternal, universal laws) for looking at and thinking about the reality encompassing all its complexity as well as a way of submerging under the visible, external world to see and to understand the true relationship linking man and the universe, man and man, and of course man and his own self. Although the interpretation of yoga proposed by Polończyk is quite extensive, and the esotericist clearly demonstrated the functions and mechanism of this raja yoga, he left practical issues almost entirely aside. Undoubtedly, the practice had an internal character, but Polończyk did not describe any specific exercises. The slightest clues as to what it might look like in his imagination can be described as: intellectual training (i.e. developing knowledge

\footnotetext{
${ }^{33}$ Ibidem, p. 14.

${ }^{34}$ Ibidem, p. 7.

${ }^{35}$ E. Polończyk, Prawda o yodze i naukach tajemnych, Warszawa 1932, p. 7.

${ }^{36}$ Ibidem.

${ }^{37}$ Ibidem, p. 5.

${ }^{38}$ Ibidem, p. 4.
} 
about the reality and the place of a human being within), awareness (in relation to changes in the world and in the individual) and mindfulness.

According to Polończyk, yoga comprehended in this way was supposed to bring an exhaustive understanding of the messages and meanings conveyed by all the symbols of every religion and sacred books in the world, ${ }^{39}$ which were in fact identical to the secret and primordial knowledge that is a foundation of the whole phenomenal world. To develop this kind of knowledge (so, in fact, to put raja yoga, the "Hindu synthesis," into practice), Polończyk explained, one needs two "beams of light," that is to look at the whole of reality through the eyes of a doctor and a historian bringing together (synthesising) two perspectives: a narrow and limited one (of the human body) and a broad, timeless one (of a long, historical time span). Polończyk clarified:

The rules of education, health and therapy cannot be found, as we have already tried, in anatomy and physiology, but we have to search for them in the history of life, art and customs of each nation, in their traditions and social sciences, in the rules of the family arrangements and politics. On the other hand, the regulations of the order and coexistence of the nations cannot be found either in the history of the peoples or in the textbooks of the social sciences and theology, but in the laws and signs of the human body and organism [...]. Looking at mankind and nations through the eyes of a doctor gives one new references and one new previously unknown source of clarity; understanding the body with the mind of a historian creates a second beam of light. From the intersection and at the same time balancing the two beams emerges a new science linking faith, religion, life and all the branches of skills in one new knowledge - this is the knowledge of Oneness, Life and Resurrection, this highest state of Power and Light, the mark of the Holy Spirit called the Wisdom. ${ }^{41}$

This kind of double, synthetic perspective, and the knowledge that may be derived from it, could not be, Polończyk asserted, "read out of books, but has to be acquired by systematic effort," ${ }^{2}$ to be developed by a particular yoga practice which consisted mainly of continuous self-improvement - moral, intellectual and spiritual. So one should deepen one's school-like knowledge (as long as it covers facts, not their interpretations ${ }^{43}$ ), but at the same time get to know in depth the sacred books

39 Ibidem.

40 E. Polończyk, Czem jest Yoga?, p. 3.

41 Ibidem. Polończyk also interprets these two beams of light using the Christian concept of the Holy Trinity. Seeing a man from the broad, historical perspective creates "a light of the Father," comprehending humanity from the perspective of a human being creates "a light of the Son" and the synthesis of the two brings the Wisdom and Truth which is the Holy Spirit (ibidem, pp. 4-5). It should be noted that all Polish interpretations of yoga created in the interwar period were of a Christian character, though it was usually an esoteric version of Christianity. It is worth adding that Polończyk, again like many esotericists of the time, was convinced that Christianity in its traditional (i.e. church-oriented) version had become degenerated and lost all its religious (spiritual) values. The true Christianity, Polończyk claimed, should be rediscovered in the process of inner experience. Its essence was embodied in the "Aryan knights and Indian raja yogi who is their most perfect type" (E. Polończyk, Synteza przyszłości, p. 48).

42 E. Polończyk, Czem jest Yoga?, p. 6.

43 Polończyk was very critical not only towards the "official medicine," as already mentioned, but also toward every kind of "official science." He wrote: "The official scholarship which abuses the name of science announced boastfully the synthesis (which is Yoga) as a crown of its work but in fact created 
of different religious and spiritual traditions. It would be particularly useful and beneficial to study and to contemplate the works of Adam Mickiewicz, as "[...] nothing among the European literary works compares to them in terms of weight, clarity and power, as they are much more than a mere poet's expression. They are the highest point reached by the thought of a mortal being, they are one of the pillars of a bridge joining the earth with immortality and true knowledge." ${ }^{\prime 4}$ An important part of this raja yoga "practice" was the habit of continuously comparing the knowledge that changed all the time due to educational endeavours with the actions that are motivated by that knowledge. Polończyk wanted a yogi to be perfectly aware of how his knowledge, which changed dynamically all the time, influenced his everyday activities, and how a yogi should modify both knowledge and actions to work better for the benefit of humanity as a whole. The next step in the yoga "practice" was to fix all these habits and knowledge in the body. Polończyk said that it was necessary to rebuild the body in order to make it work for the benefit of humanity ("the work of altruism and universal evolution"), regardless of the individual's will. ${ }^{45} \mathrm{He}$ did not, however, give any particular indications of how to do this, and how to make this transformation happen. He rejected all "tricks" and "secret means," and was also sceptical towards "esoteric methods," as in fact he considered them to be shortcuts which may "[...] only revive, enhance and perpetuate vanity, ignorance, powerlessness, virulence and other similar defects." ${ }^{46}$ The only guideline he gave was:

Yoga is to create light, to accumulate the energy, to organise life, to search for ways to unite and to build a unity, consent and oneness [...]. Such are the preliminary and basic principles of Raja Yoga, the royal wisdom of the east... ${ }^{47}$

To understand Polończyk's interpretation of yoga and to explain the mechanisms of its efficacy, it would be helpful to use Pierre Bourdieu's concept of habitus. This would seem to be the very idea underlying Polończyk's thinking, though of course expressed in altogether different categories. Habitus, as Bourdieu explains, is "[...] systems of durable, transposable dispositions, structured structures predisposed to function as structuring structures, that is, as principles which generate and organize practices and representations that can be objectively adapted to their outcomes without presupposing a conscious aiming at ends or an express mastery of the operations necessary in order to attain them." ${ }^{48}$ Habitus allows one to create new ways of thinking and perceiving reality, and creates new courses of action - new, but always remaining within the limits of the conditions in which it was developed. In Polończyk's vision, it is yoga that is supposed to build new and "open systems of dispositions," to generate certain strategies manifesting themselves in confrontation with certain situations (in this

only millions of memory dustbins which brim over with poisonous gases gathering in one international slough and, as a consequence, bringing the present catastrophe" (ibidem, p. 7).

${ }^{44}$ Ibidem, p. 12.

${ }^{45}$ Ibidem, p. 8.

${ }^{46}$ Ibidem, p. 9.

${ }^{47}$ Ibidem, p. 13.

${ }^{48}$ P. Bourdieu, The Logic of Practice, transl. R. Nice, Cambridge 1990, p. 53. 
case physical, moral and intellectual crisis, bringing social and political catastrophe). While manifesting, they structure the way of thinking, build up the knowledge and determine how to behave and act. This, it would seem, is Polończyk's idea - to create a new habitus, which would encapsulate human experience into new structures, in turn bringing a new and appropriate course of action resulting in the transformation of the entire reality.

This transformation, Polończyk stressed, should happen in every individual. A person who has realised the ideal of raja yoga, and been able to develop such a way of comprehending reality, would become a true yogi. Such a person has the power to transform the world and is identical with "Mickiewicz's eternal man, who does not stumble and fall under the burden of hardship and suffering but who is strong, full of power, wisdom, who will fight death and pain." 49 The raja yogi uses all his abilities, skills and talents not for his own purposes but for the sake of others. In this way, he realises the fundamental teachings of raja yoga, which is supposed to "raise people who want to create joy for millions and who want to suffer for millions." ${ }^{50}$ According to Polończyk, gradually introducing raja yoga into the life of every person, and especially into social practice, would provoke the necessary change, the revival of the whole of humanity, and ultimately "begin the era of the Spirit of Truth." 51

The result of this transformation induced by the raja yoga should, according to Polończyk, be the birth of a new ideal, a synarchic structure of social reality. In fact, Polończyk outlined the utopian state with the hierarchical class system, where the order of individual life would be precisely designed, and where all the citizens would be divided into separate groups depending on the significance of their work. At the same time, all these groups and individuals were supposed to cooperate with each other peacefully and efficiently. Such a state (understood as one well-functioning organism) would control all aspects of individual life to make an individual fit perfectly within the system and work in perfect harmony with the system. ${ }^{52}$ Such an order, as Polończyk saw it, would be the implementation of the natural and universal laws. For, in fact, this kind of synarchic social and political system was supposed to duplicate the order of the universe and create "synthesis." Polończyk wrote:

${ }^{49}$ E. Polończyk, Czem jest Yoga?, p. 10. This is a very clear reference to Adam Mickiewicz's drama Dziady [Forefathers' Eve], considered to be one of the finest works of European Romanticism. In his drama (especially its fourth part), Mickiewicz highlights messianic themes, weaving parallels between the suffering of Jesus and the sacrifice of Poland, persecuted and deprived of its statehood. Due to its multilevel structure as well as the exceptional richness of the symbolism, Dziady became the subject of many various interpretations, including esoteric ones. Mickiewicz's drama was also a source of inspiration for many Polish esotericists, especially those with messianic inclinations. Here Polończyk refers to Gustaw/ Konrad, the main character of Dziady. Gustaw, a romantic lover, transforms into Konrad, a hero willing to fight for the freedom of his country. Gustaw/Konrad was read as a symbol and a call to overcome the apathy and personal drama in the name of the greater and far more important case, which was the liberation and freedom of the country.

${ }^{50}$ Ibidem, p. 13. This is yet another reference to Mickiewicz's Dziady and so-called "Wielka Improwizacja" [The Great Improvisation], where Konrad demands from God his power to bring happiness to his nation and each individual.

${ }^{51}$ Ibidem.

${ }^{52}$ Cf. for example: E. Polończyk, Przyszly uktad...; idem, Przyszły ustrój...; idem, Program wykonawczy... 
The wonder of the system of the universe lies in the fact that each of the living creatures, and even celestial bodies and planetary systems, occur in a form and place, i.e. are born in the conditions which are most favourable for their development as well as the entire universe. Similarly, the cells and tissues of the human body are born. The tasks and works which every human being coming into this world finds and should fulfil are perfectly suited to his or her strength, abilities and needs; they are all identified through the eyes of wisdom, seeing past and future [...]. The way to know, the first steps, the ideas and the entire Kingdom of Truth and Liberation are therefore most accessible for every individual, for every nation, even the animals and tissues of the body, only in this environment and the conditions in which they all came into this world. ${ }^{53}$

The Arya Society, founded by Polończyk, as previously mentioned, was supposed to be a first step towards creating this utopian state. This small organisation, which was in fact insignificant at the time of its foundation, would develop, grow, and eventually encompass the whole of Poland, Europe and the whole world.

In all likelihood, it appears that in this case the French occultist Alexandre SaintYves d'Alveydre (1842-1909), who developed the idea of synarchy, was a main source of inspiration for Polończyk. D'Alveydre's book Mission de l'Inde en Europe (originally published in 1886$)^{54}$ was very well known in Polish esoteric circles. It was translated into Polish in 1921, and was almost immediately read as a call directed specifically at Poland to implement the idea of synarchy into social practice. Poland was to be the "messiah of the nations" - beginning the universal revolution leading towards the new and perfect (synarchic) world order. One widely read esoteric journal named "Odrodzenie" [The Revival] published ${ }^{55}$ such an appeal:

Some thirty years ago a great soul, Alexandre d'Alveydre, urged the whole world to undertake this work. Since, however, his voice remained unanswered [...], you - resurrected Poland, you again call the whole world [...], as d'Alveydre urged us to take up and to realise the synarchic world system [...] in the same way you Poland do it now, and we firmly believe that you will be listened to, that you will hold the helm tight and will lead humanity to the Heights of the Highest One, to a better and brighter future of humankind... ${ }^{56}$

${ }^{53}$ Idem, Arja. Część I..., p. 49.

${ }^{54}$ D'Alveydre claimed that he had met a group of Eastern Initiates (masters) from Agartha, a secret city located in the very core of the Earth. They had supposedly communicated with him telepathically, revealing not only the details considering the organisation of this mythical city, but also its location. D'Alveydre described all these revelations in Mission de l'Inde en Europe. The idea of Agartha became very popular in Poland, especially in esoteric circles. Antoni Ferdynand Ossendowski (1876-1945), a Polish teacher, journalist, social activist and explorer, contributed to the further popularisation of these ideas and authored the widely read book Przez kraj ludzi, zwierzat i bogów (konno przez Azję Centralna) [Across the Country of Humans, Animals and Gods (on Horseback through Central Asia)] (1923), in which he described, among others, his adventures in Mongolia, where he claimed to have met a group of Mongolians who had told him about this city hidden somewhere under India and Afghanistan (cf. A.F. Ossendowski, Przez kraj ludzi, zwierząt i bogów (konno przez Azję Centralna), Warszawa 1923).

55 “Odrodzenie. Miesięcznik poświęcony sprawom odrodzenia człowieka i badaniom zjawisk duchowych" [Revival. Monthly Dedicated to the Issues of the Revival of Human Being and Research of Spiritual Phenomena] published in 1921-1928 by the spiritist Józef Chobot (1875-1942). The journal published articles dealing with all sorts of esoteric issues and propagated a strongly messianic version of Polish patriotism.

56 J. Chobot, Do wszystkich ludzi dobrej woli, "Odrodzenie” 1923, no. 4, p. 6. 
In the vision outlined by Polończyk, Poland - renewed through raja yoga and "tuned" to the universal laws - was to play exactly such a role. The esotericist from Lviv saw Poland as the heart, the starting point for the process of the transformation of the world. Poland, being the "conscience of Europe," was able to accumulate all the evil and, at the same time, utter a voice "distinguishing Good and Evil, Sickness and Health $[. .$.$] the voice of future synthesis and resurrection." { }^{57}$ Polończyk wrote:

Every time and everywhere where there has been a genuine revival and healing of the body, the conscience which is the heart (understood both as an organ and a place), the first authority, had to be cleansed and healed in the first place. That is why the role which Poland accepts is an indispensable necessity of the laws of the universe. ${ }^{58}$

In his interpretation of yoga, Polończyk merged two themes. On the one hand he nurtured a longing, so characteristic for Western esoteric thought, for the revival of the world and renewal of mankind, improving it morally in order to be able to reach the spiritual reality and take advantage of its powers - an idea which was particularly strong in all the trends inspired by theosophy. On the other hand, Polończyk introduced some motifs typical of the Polish social, political and philosophical discourse of this time - messianic and Promethean - which appreciated Poland highly while showing the country as having special importance in being expected to bring salvation to the whole world. In this way, it seems, yoga became assimilated and fitted within the Polish cultural landscape. This was all the easier because Polończyk showed yoga not as a set of physical practices, but as an intellectual activity - a specific way of thinking and interpreting reality, consistent with (or at least not contrary to) the Christian worldview. This approach also allowed Polończyk to present yoga as a kind of a social practice which may or even should be carried out in a social context - ultimately it was not the individual who benefited from the practice, but the entire nation, and finally humanity.

These themes, so strongly emphasised in Polończyk's yoga - Christian, messianic, patriotic and esoteric - disappeared entirely in the understanding of yoga after World War II. The yoga developing in Poland during this period up to the 1980s, virtually without any clear organisational structures (due to - once again - the political situation) ${ }^{59}$ functioned in two ways. On the one hand - more openly and officially - primarily as a gymnastic, relaxing and therapeutic system. We can assume that this orientation of yoga resulted from two factors - firstly, yoga comprehended and presented as a set of physical exercises was acceptable (or at least was not repressed) by the totalitarian system, and secondly - even those behind the tight Iron Curtain received reports about Swami Kuvalayananda's experiments and their

${ }^{57}$ E. Polończyk, Synteza przyszłości, p. 48.

58 Ibidem.

${ }_{59}$ As a result of agreements made at the Yalta and Potsdam conferences held in 1945 after World War II, Poland entered the orbit of influence of the Soviet Union. The communist regime constructed systematically in this part of the world effectively prevented the emergence of any institutions involved in teaching and promotion of yoga. Due to the country's isolation, the flow of ideas was very much restricted. 
results, ${ }^{60}$ which became an inspiration for the development of the research in this field. There were also, of course, milieus in which yoga was comprehended with its spiritual, inner dimension - it was the second, much less official current, obviously a concern to the communist security services, which subjected them to regular surveillance (e.g. the group of people centred around the Polish-Indian Friendship Society, established in 1957). In both cases, however, the emphasis was placed on individual practice and individual results and, importantly, the stress was put on the necessity of going back to the authentic tradition of yoga, i.e. verified scientifically in the first case and by textual evidence in the second. In neither case was there any room for the "Polish interpretation" of yoga.

\section{Bibliography}

Alter J., Yoga in Modern India. The Body between Science and Philosophy, Princeton-Oxford 2004. Bourdieu P., The Logic of Practice, transl. R. Nice, Cambridge 1990.

Chobot J., Do wszystkich ludzi dobrej woli, “Odrodzenie” 1923, no. 4, pp. 2-9.

d'Alveydre St-Yves A., Misja Indyj w Europie, K. Chobot (ed.), Katowice 1921.

d'Alveydre St-Yves A., Mission de l'Inde en Europe, Paris 1886.

De Michelis E., A History of Modern Yoga. Patanjali and Western Esotericism, London-New York 2005.

Gleic A.K., Glossariusz okultyzmu, Kraków 1936.

Goodrick-Clarke N., The Occult Roots of Nazism, London 2004.

Lutosławski W., Rozwój potęgi woli przez psychofizyczne ćwiczenia, Kraków 1909.

Ossendowski A.F., Przez kraj ludzi, zwierząt i bogów (konno przez Azję Centralna), Warszawa 1923.

Polończyk E., Arja. Część I (Synteza odrodzenia), Lwów 1924.

Polończyk E., Czem jest Yoga?, Lwów 1921.

Polończyk E., Lekarze i leczenie, Lwów 1918.

Polończyk E., Prawda o yodze i naukach tajemnych, Warszawa 1932.

Polończyk E., Program wykonawczy Związku “Arja”. Rzeczpospolita z Królem, Lwów 1926.

Polończyk E., Przyszłość Polski. Żydzi. Jehowa, Lwów 1921.

Polończyk E., Przyszły układ narodów, Lwów 1919.

Polończyk E., Przyszły ustrój ludzkości wedle źródel teozoficznych, Oedesa 1918.

Polończyk E., Synteza przyszłości, "Hejnał" 1929, no. 2, pp. 42-48.

Ramacharaka Yogi, Hatha Yoga, or the Yogi Philosophy of Physical Wellbeing, Chicago 1904.

Ramacharaka Yogi, Science of Breath: A Complete Manual of the Oriental Breathing Philosophy of Physical, Mental, Psychic and Spiritual Development, Chicago 1905.

Singleton M., Yoga Body. The Origins of Modern Posture Practice, Oxford 2010.

Świerzowska A., Esoteric Influences in Wincenty Lutosławski's Programme of National Improvement. Prolegomena, "The Polish Journal of the Arts and Culture (Esoteric Studies. Polish Contributions)”2015, no 13, pp. 147-173.

${ }^{60}$ Swami Kuvalayananda (1883-1966), a key figure for the process of transnationalisation and, above all, medicalisation of yoga, a pioneer in experimental research on yoga, founder of Kayvaliadhama Yoga Institute (Lonavla, India). In the 1960s, when India maintained close relations with the Soviet Union, the results of his studies became known in the Soviet bloc. Researchers from several countries of this region visited Kaivalyadhama and studied there (for details see J. Alter, op. cit., p. $81 \mathrm{ff}$.). Tadeusz Pasek (1925-2011) was the first Pole to visit Kuvalayananda's institute, staying there in 1967/1968. 
Świerzowska A., From Ramacharaka's “Standard of the Normal Man” to Lutosławski’s Strategy of National Revival. How Ramacharaka's Interpretation of Yoga Fits with the Early Stage of Yoga Adaptation in Poland (forthcoming).

Świerzowska A., Listy o jodze. Wincenty Lutosławski do Williama Jamesa [in:] Joga w kontekstach kulturowych 2 - 05 Listy o jodze. Wincenty Lutosławski do Williama Jamesa, Katowice 2017, pp. 67-92.

Świtkowski J., Wstep w światy nadzmystowe. Radża joga nowoczesna, Katowice 1923.

Tomasiewicz J., Naprawa czy zniszczenie demokracji? Tendencje autorytarne i profaszystowskie w polskiej myśli politycznej 1921-1935, Kraków 2012.

Włodarz B., Przestańcie tworzyć sekty! Czyli prośba o duchowe pojednanie, Warszawa 1933.

Zasady rząu narodu Tolteków (Szkic z dziedziny okultyzmu), "Odrodzenie" 1921, no. 3, pp. 14-16.

Zasady rządu Tołteków (Ciag dalszy), "Odrodzenie” 1921, no. 4, pp. 12-14. 